\title{
TRANSFORMATION OF FINANCIAL REGULATORY GOVERNANCE THROUGH INNOVATION FACILITATORS - CASE STUDY OF INNOVATION HUB IN CROATIAN CAPITAL MARKETS
}

\author{
Ivana Bajakić, PhD, Associate Professor \\ Faculty of Law University of Zagreb \\ Trg Republike Hrvatske 14, 10000 Zagreb, Croatia \\ ivana.bajakic@pravo.hr
}

\begin{abstract}
Fin Techs have attracted great attention for their potentially disruptive impact on financial ecosystem. They represent a great opportunity for democratisation of financial systems and better access to finance, but also a possible risk for financial stability. Regulatory framework is trailing behind fast-moving technological advancements. Innovation facilitators, i.e. innovation hubs and regulatory sandboxes have been designed as new governance models to promote technological innovations and regulatory efficiency in financial services. The UK is a global pioneer in this area with Project Innovation that started in 2014, while other Member States followed. Croatia has established its first innovation facilitator in a form of Innovation hub in May 2019. The purpose of this paper is to examine the level of financial regulatory innovation and potential for transformation of regulatory governance from "command and control" system to more alternative and collaborative approach characteristic for innovation facilitators. Research methodology combines secondary data, semi-structured interviews and comparative assessment of UK's and Croatia's approach to financial regulatory governance, using the most different case method. Results point to incremental changes in governance culture, nonetheless a positive step forward in promoting a culture of dialogue and better policy-making.
\end{abstract}

Key words: Fin Tech, financial regulatory governance, Innovation hub, capital markets

\section{INTRODUCTION}

FinTech is defined by the Financial Stability Board (FSB) as "technology-enabled innovation in financial services that could result in new business models, applications, processes or products with an associated material effect on the provision of 
financial services". ${ }^{1}$ Financial sector is a frontrunner consumer of digital technologies. $^{2}$ There are more than 12.000 FinTechs operating globally, with a growth rate of $200 \%$ since 2010 . This trend has been decelerating since 2016, because investors became more cautious about business models and cycles. ${ }^{3}$ Fin Techs have attracted great attention for their potential disruptive impact on the financial system and could cause far-reaching change for financial ecosystem and its incumbent institutions, revolutionising access to capital and financial services for individuals, businesses and other interested participants.

Fintechs have already become a regulatory Pandora's Box for its dynamic and diversity, but foremost because they are simultaneously a great opportunity and threat to financial stability. ${ }^{4}$ The UK pioneered regulatory innovation through design of innovation facilitators, innovation hubs (IH) and regulatory sandboxes (RS) to enhance flexible and supportive regulatory governance of Fintech. Other countries worldwide have been replicating this governance regime.

There are a few studies on impacts of Fintech and its rising trend for Central and South Eastern European (CSEE) countries. ${ }^{5}$ The focus of this paper is on newest EU Member State (MS) Croatia and its recently established Innovation hub. The

1 Financial Stability Board, Fintech and market structure in financial services: Market development and potential financial stability implications, FSB, 2019, n.1, p.2,[ https://www.fsb.org/wp-content/uploads/ P140219.pdf], accessed 10. March 2019

2 European Commission, FinTech Action plan: For a more competitive and innovative European financial sector, $\operatorname{COM}(2018) 109$ final, 2018, p. 1, [https://eur-lex.europa.eu/resource.html?uri=cellar:6793c578-22e6-11e8-ac73-01aa75ed71a1.0001.02/DOC_1\&format=PDF], accessed 10. March 2019

3 McKinsey\&Company, FinTech decoded - Capturing the opportunity in capital markets infrastructure, Global Banking Practice, March 2018, [https://www.mckinsey.com/-/media/McKinsey/Industries/ Financial\%20Services/Our\%20Insights/Fintech\%20decoded\%20The\%20capital\%20markets\%20 infrastructure $\% 20$ opportunity/Fintech-decoded-Capturing-the-opportunity-in-capital-markets-infrastructure-final-web-version.ashx], accessed 10. April 2019

4 Financial Stability Board, note 1; Financial Stability Board, Artificial intelligence and machine learning in financial services Market developments and financial stability implications, 2017, [https://www.fsb.org/ wp-content/uploads/P011117.pdf], accessed 10. March 2019

5 Deloitte, FinTech in the CEE region: Charting the course for innovation in financial services technology, Department for International Trade, Deloitte, 2016, [https://www2.deloitte.com/content/dam/ Deloitte/global/Documents/About-Deloitte/central-europe/ce-fintech-in-cee-region-2016.pdf], accessed 10. April 2019; Raiffeisen Bank International, CEE FinTech Atlas 2018 - Exclusive insights into 19 Fintech ecosystems in Central and Eastern Europe, 2019, [http://www.fintechatlas.com/], accessed 10. April 2019; Kerényi, Á., The Fintech Challenge: Digital Innovations from Post-Communist EU Member Countries, Centre for Economic and Regional Studies of the Hungarian Academy of Sciences - Institute of World Economics, 2018, p. 1-47, [http://www.tepsa.eu/the-fintech-challenge-digital-innovations-from-post-communist-eu-member-countries-adam-kerenyi-iwe-hungary/], accessed 10. April 2019; Stern, C., Fin Techs and their emergence in banking services in CESEE, Focus on European Economic Integration, Q3/17, Oesterreichische Nationalbank, 2017, p. $42-58$ 
purpose is to examine the level of financial regulatory innovation and potential for transformation of regulatory governance from "command and control" system to more alternative and collaborative approach characteristic for innovation facilitators. $^{6}$

Research methodology combines secondary data, semi-structured interviews and comparative study of UK's and Croatia's approach to financial regulatory governance, using most different case method. ${ }^{7}$ They are combined to identify similarities and differences in regulatory approaches in order to evaluate impact that Innovation hub could have on alteration in internal culture of Croatian financial regulatory authorities (Annex 2). Furthermore, Croatian IH was compared to all Member States that have operational IHs analysed in the ESAs' Report ${ }^{8}$ (Annex 1). Semi-structural interviews were conducted during second half of 2019 with high-level officials and experts from public and private financial sector that is Fintech related. Additionally, information from the newly opened IH by the Croatian National Bank (CNB) was added, based on basic information provided on their IH's website. ${ }^{9}$

Following short introduction, the paper provides brief background of European regulatory governance generally and more specifically with regard to Fintech and innovation facilitators. It also presents key aspects of regulatory financial innovation in the UK. Fourth part is based mostly on empirical evidence from interviews on FinTech and organisation and operation of Innovation hub in Croatia. Fifth part examines the level of transformation of financial regulatory governance through case study of Innovation hub combined with opportunities and challenges of policy-making in Croatia while final chapter summarizes the main conclusions.

6 Zeitlin, J., Transnational Transformation of Governance - The European Union and Beyond, Vossiuspers UvA, Amsterdam, 2010, [https://pure.uva.nl/ws/files/1507269/93675_342972.pdf], accessed 10. March 2019

7 Seawright, J.; Gerring, J., Case Selection Techniques in Case Study Research - A Menu of Qualitative and Quantitative Options, Political Research Quarterly, vol. 61, no. 2, 2008, p. 294-308

$8 \quad$ ESAs, European supervisory authorities: European Security and Markets Authority, European Banking Authority, European Insurance and Occupational Pensions Authority, Report - Fin Tech: Regulatory sandboxes and innovation hubs, ESMA, EBA and EIOPA, JC 2018 74, 2019, [https://eba.europa.eu/ documents/10180/2545547/JC+2018+74+Joint+Report+on+Regulatory+Sandboxes+and+Innovation+Hubs.pdf], accessed 10. May 2019

9 Croatian National Bank, Innovation hub, [http://fintechhub.hnb.hr/home], 2020, accessed 10. January 2020. CNB's IH has a secondary focus and relevance for this study since Croatia has divided financial regulation and supervision on banking and non-banking sector with two public authorities, namely CNB and HANFA (Croatian Financial Services Supervisory Agency) and the primary focus of this paper is on Croatian capital markets 


\section{EUROPEAN FINANCIAL REGULATORY GOVERNANCE}

Competition is a fundamental force of efficient financial markets. European policies have a long-term record of imposing competition on European financial systems, e.g. Lisbon strategy, Financial Services Action Plan, Capital Markets Union, Single Euro Payment Area. Despite many positive changes, European financial playground still lacks vibrant allocation of resources. ${ }^{10}$ But if we hypothetically set aside the reason these policies were initiated, i.e. competitiveness of European financial markets, transformation of European financial governance has provided new set of powers and supplementary global influence for the EU. ${ }^{11}$ Couple of convenient circumstances have contributed to this development, e.g. single currency in the EU, corporate scandals in the US, global financial crisis. ${ }^{12}$ Because of its unique political setup, the EU had to apply matrix of things to enhance Single European Financial Market. Massive financial regulatory reform was executed through Financial Services Action Plan, introducing new methodology set up of the Lamfalussy Process, formulating procedural reform through comitology of financial services, multilevel and network arrangements, which ensured speed of legislative process. ${ }^{13}$ By the time implementation was receiving first positive and negative impact assessments, the Global financial crisis (GFC) has created imperative demand for new regulatory and supervisory reform, which also created momentum for supranational power enlargement. "A crisis is a terrible thing to waste" 14 and Committee of European Securities Regulators' - CESR's ambitions to grow in authority proved their critics wrong. Not only that so-called "Himalaya Report"15 did not "sink like a Titanic"16 but it reached quite the opposite stellar dimension. In the post GFC regulatory environment, CESR was transformed into

10 European Central Bank, 2009-2019 - Surveys on Access to Finance for Enterprises, [https://www.ecb. europa.eu/stats/ecb_surveys/safe/html/index.en.html], accessed 10. March 2019; World Economic Forum, The Europe 2020 Competitiveness Report, building a more competitive Europe, 2014, [http:// www3.weforum.org/docs/WEF_Europe2020_CompetitivenessReport_2014.pdf], accessed 10. May 2019

11 Mügge, D. (ed.), Europe and Governance of Global Finance, Oxford University Press, 2014

12 Mügge, D., Introduction, in Mügge, D. (ed.) Europe and Governance of Global Finance, Oxford University Press, 2014, p. 1-15

13 Posner, E., The Lamfalussy Process: Polyarchic Origins of Networked Financial Rule-Making in the EU, in: Sabel, F.; Zeitlin, J., (eds.), Experimentalist Governance in the European Union - Towards a New Architecture, 2012, p. 43-60

14 Lannoo, K., A crisis is a terrible thing to waste, CEPS Commentary, [https://www.ceps.eu/wp-content/ uploads/2009/08/1847.pdf], 2009, accessed 10. March 2018

15 Committee of European Securities Regulators, Preliminary Progress Report: Which supervisory tools for the EU securities markets? An analytical paper by CESR, Ref 04-333f, CESR, 2004, [https://www.esma. europa.eu/sites/default/files/library/2015/11/04_333f.pdf], accessed 10. May 2019

16 European Commission, Results of the Commission's "Exchange of views" on Financial Services Policy 2005-2010, Brussels, $18^{\text {th }}$ July 2005, p. 5 
new European securities supervisory authority - ESMA ${ }^{17}$ along with two supranational bodies in their field, European Banking Authority - EBA and European Insurance and Occupational Pensions Authority - EIOPA. ${ }^{18}$ Finally, Fintech is a product of financial globalisation requiring co-ordination of regulatory and supervisory bodies worldwide and the EU has acquired superior know-how in this area. ${ }^{19}$

\subsection{European regulatory governance for FinTech and innovation facilitators}

How to effectively regulate FinTech? It appears like a Sisyphean task - FinTech is such a dynamic and fast changing sector in which laws are outdated almost by the time they enter into force. Additionally, traditional financial regulation is rather stringent, because historically it needed to prevent (and punish) fraud and systemic risk. Furthermore, financial crises evolve because promising financial innovations have an affair with moral hazard, bad risk evaluation and inadequate regulation and supervision. In that respect, Fintech has destructive potential for customer fraud and systemic risk.

Nevertheless, FinTech has a distinctive social innovative potential that should give regulatory authorities courage to be flexible and take risks. FinTechs are already reshaping financial ecosystem through challenging incumbents and providing customers with better and cheaper financial products and services. Empirical studies show that this process is not a "Game of Thrones", rather a combination of competition and collaboration. ${ }^{20}$ FinTech revolution lays in its potential to democratise financial systems. FinTechs are changing financial systems by upgrading the core function of a financial system - efficient allocation of resources. New

17 Moloney, N., The Age of ESMA - Governing EU Financial Markets, Hart Publishing, Oxford, UK, 2018

18 Wymeersch, E., The institutional reforms of the European Financial Supervisory System, and interim report, Financial Law Institute, Gent University, WP 2010-01, 2010; Moloney, N., The European Securities and Markets Authority and Institutional Design for the EU Financial Market - A Tale of Two Competences: Part (1) Rule Making, 12 European Business Organization Law Review, 2011, p. 41-86; Ferran, E., Crisis-driven regulatory reform: where in the world is the EU going?. in: Ferran, E. et al. (eds.), The Regulatory Aftermath of the Global Financial Crisis, Cambridge University Press, 2012, p. 29-54

19 Ferran, E., Financial Supervision, in Mügge (ed.), note 11, p. 16-34

20 McKinsey\&Company, note 3; FSB, note 1; World Economic Forum \& Deloitte, Beyond Fintech: A pragmatic assessment of disruptive potential in financial services, Part of the Future of Financial Services series, 2017, [http://www3.weforum.org/docs/Beyond_Fintech_A_Pragmatic_Assessment_of_Disruptive_Potential_in_Financial_Services.pdf], accessed 10. May 2019; World Economic Forum\& Deloitte, The Future of Financial Services - How disruptive innovations are reshaping the way financial services are structured, provisioned and consumed, An industry project of the Financial Services Community, Final Report, 2015, [http://www3.weforum.org/docs/WEF_The_future_of_financial_services. pdf], accessed 10. May 2019 
platforms are skipping traditional financial intermediaries and more efficiently connect supply and demand of individuals and businesses on a global scale, providing capital for literally any project with sufficient demand. These projects can come from individuals with innovative ideas, businesses, entrepreneurs, NGOs, governments, etc. Fintechs therefore have potentials to democratise the financial system by diminishing power structures of incumbent financial institutions such as banks, insurance companies, stock exchanges, e.g. Facebook's crypto-currency Libra. It would be naïve to think "the power will go to the people". New champions will most likely be data intensive and platform-based business models. ${ }^{21}$ Therefore, future regulation will probably be most challenging in areas of data protection, digital rights and ethical standards. Nevertheless, it is providing unprecedented set of opportunities for capital raising and financial borrowing at so many different levels, allowing individuals and groups the opportunity to materialise their innovative projects.

Presently, European Fintech regulation is still in a developing phase. It addresses two interlinked EU policies, the Capital Markets Union and Digital Single Market. The European Council and the European Parliament want to see FinTech development across the EU with flexible arrangements enhancing cross-border operations and investments. ${ }^{22}$ The Fintech Action Plan is therefore focused on policy measures supporting Fin Tech development across European markets rather than building a regulatory framework. ${ }^{23}$

At a European level, innovation facilitators are designed as new governance models to promote technological innovations in financial services through a more interactive relationship between regulatory authorities and firms. The UK is a global pioneer in this area with Project Innovation that started in 2014, while other Member States followed with operational innovation hubs during 2016-17 and acceleration of regulatory sandboxes during 2018-19. ${ }^{24}$

$21 \quad$ Ibid.

22 European Council, European Council meeting - Conclusions, General Secretariat of the Council, 19 October 2017, Brussels, [https://www.consilium. europa.eu/media/21620/19-euco-final-conclusions-en. pdf], accessed 10. March 2018; European Parliament, Report on FinTech<Titre $>$ : the influence of technology on the future of the financial sector, $</$ Titre $>,<$ DocRef $><$ Commission $>\{$ ECON $\}$ Committee on Economic and Monetary Affairs</Commission $>$, Rapporteur: <Depute $>$ Cora van Nieuwenhuizen, 2017, [</Depute>, 28.4.2017, http://www.europarl.europa.eu/doceo/ document/A-8-2017-0176_ EN.html], acessed 10. April 2019

23 European Commission, note 2.

24 ESAs, note 8; Cambridge Centre for Alternative Finance, Academy of Internet Finance, Guide to promoting financial \& regulatory innovation - Insights from the UK, University of Cambridge Judge Business School, Zheijang University, 2018, [https://www.jbs.cam.ac.uk/fileadmin/user_upload/research/ 
Innovation hubs operate as an information desk with trained professionals giving non-binding guidance and support regarding regulatory and supervisory issues. It is designed as a mutually useful meeting point, i.e. on the one hand, it provides FinTechs with information and clarification regarding regulatory and supervisory expectations in a timely manner and, on the other hand it provides regulatory authorities with market data on innovation in financial services and information about policy (re)directions.

Regulatory sandboxes are organisational units that function as a laboratory for testing innovative financial products, services, business models or delivery mechanisms. It is designed as a vibrant meeting point where both parties work closely together in an open and truthful collaboration. Regulatory authorities are openminded in exploring regulatory possibilities for new financial prototypes, fast tracking it to the market but dedicated to sustaining market integrity and investor protection. It does not mean that rules are not applied. All EU regulatory sandboxes operate by the EU and national financial rulebook, having limited space for waivers.

The following sections will closely examine two starkly different cases of innovation facilitators - one "going live" in a country with enormous financial leverage and regulatory salience in the EU, used to thinking outside the box - the UK. The other, only making its first attempts in a country that struggles to break away from bank-domination in the financing of the economy - Croatia.

\section{REGULATORY FINANCIAL INNOVATION IN THE UK}

The UK is considered a global leader in financial and regulatory innovation, exporting its financial regulatory methodology worldwide. London is ranked fourth on the Global Fintech Hubs list, ${ }^{25}$ accounting for approximately $70 \%$ of European volume. ${ }^{26}$ The UK is in the top scoring indicators for competitiveness, qual-

centres/alternative-finance/downloads/2018-06-ccaf-whitepaper-guide-to-promoting-financial-regulation-innovation.pdf], accessed 10. April 2019

25 Academy of Internet Finance et. al., The Future of Finance is Emerging: New Hubs, New Landscapes Global Fintech Hub Report, 2018, [https://www.jbs.cam.ac.uk/fileadmin/user_upload/research/centres/alternative-finance/downloads/2018-ccaf-global-fintech-hub-report-eng.pdf], accessed 10. May 2019

26 Ziegler, T. et al., Shifting Paradigms - The $4^{\text {th }}$ European Alternative Finance Benchmarking Report, Cambridge Centre for Alternative Finance University of Cambridge Judge Business School, University of Agder School of Business Law, Invesco, CME Group Foundation, 2019, [https://www.jbs.cam.ac.uk/ fileadmin/user_upload/research/centres/alternative-finance/downloads/2019-04-4th-european-alternative-finance-benchmarking-industry-report-shifting-paradigms.pdf], accessed 10. March 2019; Demertzis, M.; Merler, S.; Wolff, G., Capital Markets Union and the FinTech Opportunity, Journal of Fi- 
ity of institutions, rule of law, innovativeness, ease of doing business, etc. ${ }^{27} \mathrm{Com}$ paratively to other European countries, the UK has an exceptionally developed financial system that is market-based with a long regulatory tradition of promoting competition, i.e. business-friendly regulatory governance without destructive preferential treatment to market incumbents and high consumer protection lev$\mathrm{el}^{28}$

The Project Innovate started as an idea of two to three people in the Financial Conduct Authority - FCA. Their unique regulatory style consists of an "ego-killing" approach, ability to listen and engage in a massive public consultation process, know-how in constructing regulatory innovation agenda in collaboration with other stakeholders, speed and flexibility in making changes where they can increase customers benefits and finally, all of the above managed without undermining its own authority and integrity. ${ }^{29}$

Firstly, the FCA stated publicly that they weren't doing "that great of a job" in promoting innovations. "Regulators are known for some of the very high-profile stuff we do, which is dealing with things that go wrong in markets, but our overarching objective is to make markets work well. And that's much more than just dealing with misconduct, it's making sure that the right products come into market, making sure that innovators feel they have the ability to launch it to markets, and I felt we weren't doing that well enough. So, this project is addressing a gap, and that gap is about people's ability to launch new products, to innovate.... and it's us being sensitive to where our rules, where the rulebook, where the regulations actually just don't make sense for people wanting to do a different type of business. Hub therefore need to challenge us, the FCA, to change those processes, to change those rules where we think it's in the best interest for consumers." ${ }^{30}$

Secondly, the FCA published Call for input, wanting to know what triggers difficulties for innovator businesses in a regulatory system and what practical help do small innovators need from IH. The FCA found out there are many areas in which

nancial Regulation, vol. 4, issue 1, 2018, pp. 157-165, [https://doi.org/ 10.1093/jfr/fjx012], accessed 10. March 2019

27 World Bank, Doing Business 2019 - Training for Reform, 16 ${ }^{\text {th }}$ edition, 2019, [http://www.doingbusiness.org/content/dam/doingBusiness/media/Annual-Reports/English/DB2019-report_web-version. pdf], accessed 10. May 2019

28 Black, J., Regulatory Styles and Supervisory Strategies, in: Moloney, N.; Ferran, E.; Payne, J. (eds.) The Oxford Handbook of Financial Regulation, Oxford University Press, 2015; Armour, J. et al., Principles of Financial Regulation, Oxford University Press, UK, 2016

29 Cambridge Centre for Alternative Finance, note 24

30 Financial Conduct Authority, Martin Wheatley, FCA's Project Innovate "Innovation Hub" launches, video, 2014, [https://www.youtube.com/watch?v=PmSALpjHnoo], accessed 10. March 2018 
they fail to support innovators properly, e.g. difficulties to navigate the regulatory system, lack of legal certainty, inadequate FCA website information. This helped them to focus and prioritise areas important to the innovators' community. ${ }^{31}$

Finally, managing change is a process that requires competent and dedicated experts engaging in literally hundreds of meeting activities, preaching and proactively spreading policy ideas, enchanting in public consultation and receiving valuable information that can help identify possible policy and process changes. These included: roundtables, "surgeries", thematic workshops, monthly showcase events, events and conferences, consultation processes, innovation sprints, along with workshops, roadshows, roundtables, conferences and panel sessions hosted by other organisations. ${ }^{32}$ By 2018, the FCA's Innovation hub supported over 500 firms and additional 70 firms through regulatory sandboxes. ${ }^{33}$

\section{FINTECH AND INNOVATION FACILITATORS IN CROATIA - VIEW FROM THE BOX}

Croatian financial market is a bank-based system. ${ }^{34}$ Retail banks, in more than $80 \%$ of foreign ownership, are focused on traditional operations such as savings and loans. Subsequently, policy initiatives for more diversified operations and financial markets development fall short because of underdevelopment of Croatian financial market, e.g. securitisation, covered bonds.

Fintech is in embryonic stage in Croatia, counting app. 15 FinTechs in 2018. ${ }^{35}$ There are some Croatian IT firms generating technological solutions for domestic and foreign financial institutions: COMBIS, IN2 for Croatia Bank and Incendo for Splitska Bank; regional players: Asseco for most of Croatian banks, including Zagrebačka Bank, Comtrade for Addiko Bank, ${ }^{36}$ as well as centrally developed software solutions by foreign "parent" bank and implemented locally in bank's subsidiaries, e.g. George, new platform for communication with retail clients in

\footnotetext{
31 Cambridge Centre for Alternative Finance, note 24, p. 13

32 Ibid., p. 14, 42-43

33 Woolard in UNSGSA FinTech Working Group and CCAF, Early Lessons on Regulatory Innovations to Enable Inclusive FinTech: Innovation offices, Regulatory Sandboxes, and RegTech, Office for the UNSGSA and CCAF: New York, NY and Cambridge, UK, 2019, [https://www.unsgsa.org/ files/2915/5016/4448/Early_Lessons_on_Regulatory_Innovations_to_Enable_Inclusive_FinTech. pdf], p. 56, accessed 10. March 2019; Cambridge Centre for Alternative Finance, note 24, p. 56

34 Croatian National Bank, Annual Report 2017, CNB, 2018, [https://www.hnb.hr/documents/20182/2521149/e-gi-2017.pdf/d1605b20-e073-442b-8a36-704db15c051b], accessed 10. March 2019

35 Raiffeisen Bank International, note 5

36 In Deloitte, note 5, p. 106
} 
Erste Bank. Aircash is a Croatian pioneer FinTech providing P2P payments. Another rare example is Oradian, focusing on financial inclusion. So far, FinTechs had the greatest impact in the banking sector, firstly in the payments system, followed by back office and credit risk (due to development in artificial intelligence) with indications of high frequency trading development within next 5 years. There are signals of Fintech products and services inflowing the insurance market.

Croatian capital market is classified as MSCI Frontier Emerging Market. ${ }^{37}$ According to Cambridge Centre for Alternative Finance, Croatia makes $0.004 \%$ of the European alternative finance market in 2017, measured by comparative market volumes of alternative finance transactions. ${ }^{38}$ Comparatively, that is a $1.2 \%$ market share in South East Europe (SEE), 1.2 times bigger than Serbia, 32 times smaller than Slovenia, 22 times smaller than Bulgaria and Romania. In Croatia, as well as other SEE markets, foreign platforms outnumber local platforms, with usually one model type dominating the entire alternative finance volume, e.g. $\mathrm{P} 2 \mathrm{P}$ consumer lending in Bulgaria, invoice trading in Slovenia, reward- and donation-based crowdfunding in Greece. ${ }^{39}$ Estonian Funderbeam, an equity-based crowdfunding is a leader in alternative finance since its establishment in Croatia in 2017. Funderbeam SEE is $20 \%$ owned by the Zagreb Stock Exchange (ZSE). ZSE was characterised as very innovative for its proactive approach to FinTech. Alongside collaboration with the Funderbeam platform for start-up financing, it has also initiated its own platform for SMEs financing called Progress. ZSE's goal is to collaborate with Fintech to support growth for start-ups and SMEs, which will, hopefully, lead them to be listed on ZSE and included in the regulated market.

Respondents have identified some positive changes and opportunities powered by Fintech and number of obstacles for FinTech development in Croatia. Generally, they believe Fintechs are bringing benefits for consumers, providing them with more options, i.e. better, faster and cheaper service. FinTech will cut banks margins, which will lead to more competition and improved competitiveness of Croatian financial markets. One respondent perceived Fintech as an opportunity to bypass intermediary technologies and catapult straight to the most advanced solutions for Croatian capital market. There are indicators pointing that FinTech has growth potential in Croatia, e.g. IT is the fastest growing industry in Croatia supported by excellent higher education in STEM area.

\footnotetext{
37 MSCI, MSCI Croatia Index, 2019, [https://www.msci.com/documents/10199/c0db0a48-01f2-4ba9ad01-226fd5678111], accessed 10. April 2019; MSCI, MSCI Emerging Markets Index, 2019, [https:// www.msci.com/documents/10199/c0db0a48-01f2-4ba9-ad01-226fd5678111], accessed 10. April 2019

38 Ziegler et al., op. cit., note 26

$39 \quad$ Ibid., p. 134-135
} 
Respondents have identified following obstacles for FinTech development in Croatia:

- Regulatory uncertainty - sluggish pace of keeping up with technological innovations (e.g. ESMA with regard to crypto-currencies and consequently spill-over effect on MS national regulatory authorities - NRAs) and lack of clear regulatory framework,

- Accountability issues - who will be responsible in case of FinTech failure at detriment for consumers,

- Bank-based system - retail banks with traditional financial products and slow on financial innovations (private banker vs. online services); bank have weak interest in financing FinTechs,

- Absence of locally available venture capital,

- Non-supportive institutions - absence of proactive approach of NRAs: "They don't seem to be willing to step out of their comfort zone",

- Lack of intensive workshops, roundtables and other activities, not only from regulatory authorities, but also from academia and business supporting institutions (chambers, associations...),

- Lack of public policy support for the IT sector - high income tax and absence of double taxation agreements between the USA and Croatia.

Regulatory and supervisory framework has changed radically in Croatia over the last decade due to post-financial crisis regulatory reform and transposition to EU law due to 2013 EU accession. CNB has even before the crisis conducted strict and for that time rather unconventional macroprudential policy (e.g. penalties for excessive credit growth, high reserve requirements). Fortunately, these measures ensured stability for Croatian financial system during the crisis, although economic slowdown could not be avoided anywhere in Europe. MiFID I \& II has completely reshaped regulatory and supervisory landscape of Croatian capital markets. Most investment firms have closed or consolidated their businesses because of regulatory changes and/or financial crisis. All respondents agree there is an enormous burden on both public and private sector in implementation and compliance with EU law. Additionally, EU regulation is addressing sophisticated financial instruments and services, emphasising competition, while Croatian capital market has modest levels of volume, liquidity and alternative trading venues, requiring more basic regulatory framework. There are no additional laws governing Fintech. In March 2018, the European Commission presented a proposal for a regulation on crowdfunding service providers, which should enter into force during Croatian presidency of the EU in 2020. One respondent raised concerns 
about negative effects implementation of crowdfunding regulation might have on Croatian capital market's efficiency because of possible gold-plating.

Croatia has two national regulatory authorities for the financial system, CNB covering banking sector and HANFA - covering non-banking sector. HANFA has established Innovation hub in May 2019. In the period between 2017-18 there were number of enquires, mostly concerning crypto-currencies that indicated a demand for a specialist devoted to Fintech in HANFA. Additionally, committees on the EU level have also advocated for establishment of innovation facilitators in MS. HANFA also wanted to send out a signal that they are open for Fintech and want to learn about new trends and innovative models. The main motive is to enhance Croatian capital markets and lower the risk of missed opportunities as well as keep close attention to potential risks because of new technologies. In addition, HANFA's goals include fast-tracking application procedure for authorisation. HANFA's IH is open for firms from EU and worldwide, communicating in Croatian and English. Innovation hub has full support of HANFA's leadership (Annex 1).

In the preparation phase, HANFA has not conducted specialised analysis or public consultations to identify key issues and challenges with regard to FinTech. For the establishment of Innovation hub, HANFA has used in-house experts, following ESAs' "Principles for establishment and operation of innovation facilitators" 40 and other MS experiences. Innovation hub is placed within the Regulatory harmonisation and international cooperation division, having 2 people dedicated primarily to Innovation hub and 9 on flexible basis throughout HANFA's departments, with a prospect for enlargement. Enquiries are placed through standardised application form, screened by 2 coordinators. Admissibility assessment is preformed within a week. In case of a positive screening test, the enquiry is than forwarded to specialised unit (e.g. capital markets, insurance department, etc.) HANFA's IH is a member of the European Forum for Innovation Facilitators - EFIF, platform supporting EU institutions' efforts with regard to Fintech, has initiated bilateral agreements outside the EU (e.g. Israel, Abu Dhabi), exchange of information with CNB's IH and is open for co-operation with other authorities within Croatia, e.g. consumer protection, competition, data protection.

HANFA has organised a kick-off meeting with 30 representatives of app. 20 consultancy and legal firms working in the area of new technologies, followed by a series of meeting with dozens of individual firms. In the first months of IH's operations there was a moderate demand for IH's support, mostly from foreign

$40 \quad$ ESAs, note 8 
and non-regulated parties, dominantly from insurance sector. This trend has been shifting more towards MiFID financial services area and has matured into more concrete projects. Some practices of other IHs show that regulated parties do not utilise innovation hubs' services because they already have established channels of communications. Very early first impressions point to promising collaboration with FinTech and their concerns remain in the area of finding and retaining staff and possible bad risk assessment.

HANFA is open to regulatory adjustments if there is evidence that they are obstructing innovations, following criteria of investor protection and systemic risk observations. However, this type of regulatory changes is rather slow. HANFA could make faster alterations if they are within their jurisdictions, e.g. ordinances. HANFA also made it very clear that transformation of regulatory governance has very limited range. This is because Croatian administrative process is very formal, strict and hierarchical. Therefore, Innovation hub is primarily designed to help innovative firms get to the market faster and less costly.

With regard to possibilities of HANFA establishing a regulatory sandbox in Croatia, it is too early. There is no opposition, however, comparative experiences show that it is very costly operation and anecdotal evidence suggests that regulatory sandboxes are very efficient only in London and Singapore. UNSGA FinTech Working Group analysis is on the same track, stating that is it extremely resource intensive, takes between 6-18 months to develop and warns that app. $25 \%$ of established sandboxes might have too high of ambitions because of this "highprofile indicator of regulatory innovations". ${ }^{41}$

Croatian National Bank has just recently established an Innovation hub for banking and payment services. ${ }^{42}$ So far, it operates as a website through which FinTechs can ask questions with regard to regulatory requirements through the standardised application form. CNB considers innovation facilitators to be a constructive approach to exploring regulatory options with regard to Fintech. Prior to the $\mathrm{IH}$, $\mathrm{CNB}$ has established in-house FinTech working group, formed by experts from different departments with a goal to observe and analyse trends on FinTechs, report to the management, educate other departments regarding Fintech, etc. They

UNSGSA, note 33 , p. 31

42 Croatian National Bank, note 9; Croatian National Bank, Guverner Vujčić predstavio Inovacijski hub HNB-a, 17 December 2019, [https://www.hnb.hr/-/guverner-vujcic-predstavio-inovacijski-hub-hnb-a? inheritRedirect=true\&redirect=https $\% 3 \mathrm{~A} \% 2 \mathrm{~F} \% 2 \mathrm{Fwww} \cdot \mathrm{hnb}$. hr\%2Fpretraga\%3Fp_p_id\%3Dcom_liferay_portal_search_web_portlet_SearchPortlet\%26p_p_lifecycle\%3D0\%26p_p_state\%3Dmaximized\%26p_p_mode\%3Dview\%26_com_liferay_portal_ search_web_portlet_SearchPortlet_mvcPath\%3D\%252Fsearch.jsp\%26_com_liferay_portal_search_ web_portlet_SearchPortlet_keywords\%3Dinovacijski\%2Bhub], accessed 10. January 2020 
have also established co-operation with Faculty of Engineering, which provides informative and educational support. They had number of consultative meetings with banks and other FinTechs, upon their requests. Additionally, they are cooperating with other national banks to discuss developments in FinTech sector. CNB has so far not organised public consultation or published a research on Fintech in Croatia. ${ }^{43} \mathrm{CNB}$ respondent stated that they are "very aware of situation and dynamics for the Fintech area in Croatia", and described regulatory approach toward FinTech: "Our legal responsibility is to keep bank deposits safe. As long as Fintech does not jeopardise savings we keep monitoring only. However, we are very cautious with regards to crypto-currencies".

During the preparation period for establishment of HANFA's and CNB's innovation hubs, there was no discussion of possibility to have a joint innovation hub. Notwithstanding, HANFA, CNB and the Ministry of Finance have several protocols and memorandums in place since 2008 for information exchange and cooperation in the area of financial stability and supervision. ${ }^{44}$

\section{REGULATORY INNOVATION AND TRANSFORMATION OF FINANCIAL REGULATORY GOVERNANCE THROUGH INNOVATION FACILITATORS IN CROATIA}

Financial regulatory governance of NRAs in Continental Europe can be characterised as predominantly "command and control" system. It is characterised as strict and conservative, has formal hierarchical management structure, very detailed set of rules, what is permitted and what is illegal and principal-agent relationship between regulator and regulated entities. ${ }^{45}$ Financial governance has good argumentation for such a set-up. Historically, financial regulation was built up trying to prevent and punish financial fraud. Problems of asymmetric information were approached from a principal-agent supervisory arrangement. Secondly, financial systems can have far-reaching detrimental effect on economies and societies in case of crisis, with potential global spill-over effect, so controlling systemic risk and moral hazard requires non-relaxed approach and constant looking for possible suspects.

\footnotetext{
43 It has been identified as key priority research area for 2019, see Croatian National Bank, Research Priorities Programme, 2018, p. 5, [https://www.hnb.hr/documents/20182/2569921/ep21112018_istrazivacka-konferencija_dokument.pdf/4f584313-e330-4f89-8d43-5752eb19dd52], accessed 10. March 2019

44 Croatian National Bank, Cooperation with institutions in the Republic of Croatia, 2015, [https:// www.hnb.hr/core-functions/financial-stability/roles-and-cooperation/cooperation-with-institutions-in-the-republic-of-croatia], accessed 10. March 2019

45 Zeitlin, op. cit., note 6
} 
On the other side, regulatory sandbox is more alternative and experimentalist governance approach. ${ }^{46}$ It is based on collaboration between regulators and (un) regulated parties in a joint project characterised by trust and partnership. Parties are on the "same side" doing their best to help innovative projects get to the market faster, easing up unnecessary regulatory burden where possible. It also provides flexibility that is crucial for innovations. Innovation hubs are also based on promptness, competences and approachability of dedicated experts in regulatory authorities, helping innovative business navigate more easily through financial regulatory system. It is considered a useful platform for identifying regulatory obstacles and policy adjustments, e.g. Netherland's Authority for Financial Markets - AMF revised interpretation of some rules. ${ }^{47}$

Most of respondents were positive about opportunities Innovation hub could have in Croatia on a better quality of communication between regulator and private sector. One respondent stated that a case of good project, where innovative firm receives fast and approachable guidance on regulatory and supervisory requirements (and if needed fast-track for authorisation process), gets faster access to the market and proves to be a value added for consumers, will be a good signal for both private sector and regulator that they can work together and build trust relationships. This way, when the parties meet again for discussion on unnecessary regulatory burden or bureaucratic obstacle, they could be more open for dialogue and changes, conditioned that subject matter is not singular self-interest and will bring more operational efficiency for the market and consumers. This hypothesis was somewhat acknowledged by respondent from regulatory authority who pointed that communication with Fin Tech representatives are already a good sign of dialogue and step forward in building culture of consultation.

Nevertheless, transformation of regulatory governance is very limited because of the nature of administrative process in Croatia. It is very formal, strict and hierarchical. Innovation hub is designed to help innovative firms get to the market faster and less costly. Respondent agreed that regulatory authority is open to regulatory adjustments if there is evidence that current state is obstructing innovation, under criteria of investor protection and risk observation. However, this process is slow because the procedure of changing laws includes other institutions (e.g. Ministry of Finance) and is a lengthy procedure. They can make faster alterations if they are within their jurisdictions, e.g. ordinances. Another respondent warned that

\footnotetext{
46 Ibid.

47 UNSGSA et al., op. cit., note 33, p. 20
} 
some firms have different agendas: single-minded self-interest that are not in accordance with public good, some foreign companies do not have strategies in line with best interest of Croatian fiscal policies, some managers have criminal record and there is a threat of money laundering (e.g. Danske Bank scandal in Estonia, recent CNB's investigation of Zagrebačka Bank).

Most different case selection evaluation between Croatia and the UK point that Croatia is a trend-follower (Annex 2). Like many EU Member States, it has established Innovation hub following UK regulatory innovation concept but following ESAs and EU MS list of recommendations. ${ }^{48}$ Croatian NRAs were not engaged in extensive public consultation. Furthermore, neither of regulatory agencies published a study on Croatian FinTech market or a policy paper to be a starting point for public dialogue (or the academic community for that matter). According to the FCA, it is crucial to understand your starting position and get feedback from the other side about operational problems due to regulatory issues, in order to filter out ideas and policies that are in the best interest of consumers and market development. ${ }^{49} \mathrm{CNB}$ and HANFA do not have joint Innovation hub and this could cause operational inefficiencies once the $\mathrm{IH}$ gets more workload. Experiences of other MS with IHs point that close co-operation between public institutions is essential because Fintech operations are cross-sectoral..$^{50}$

There is also a question of incentive to transform financial regulatory governance. Perception of respondents about Croatian National Bank is generally positive and they are viewed as "very competent and politically independent Croatian institution". In the last couple of years, the CNB has been in the public eye because of the Swiss francs (CHF) loans. Due to dramatic appreciation of CHF, large number of loans denominated in CHF created massive default on those loans. Public reacted in outrage and legal actions. This could lead the CNB to be more risk avoidant and approach carefully regulatory and policy matters with regard to Fintech. HANFA has proven in action through Innovation hub's establishment its willingness to promote and support FinTechs. They have full support of leadership for IH's operations. However, perception of the HANFA's political independence is lesser then CNB's because of the recent change of management due to Agrokor bankruptcy procedure, the largest Croatian privately held company covering food and retail sector across the SEE region. The Government view was that HANFA did not monitor and act accordingly. This could also lead to risk avoidant behaviour by HANFA towards FinTechs.

\footnotetext{
$48 \quad$ See note 8

49 Cambridge Centre for Alternative Finance, note 24

50 ESAs, note 8
} 
The current talks between FinTechs and NRAs are conducted in-house with press release that covers general agenda vs. on-line streaming of public consultations organised by the European Commission available to wider audience on the web $24 / 7 .{ }^{51}$ Respondent from regulatory authority stated that very often, they organise events on other regulatory matters with stakeholders as public consultations but the culture of public dialogue is underdeveloped in Croatia. Private sector often turns to informal channels of communications. This comment is in line with research on business environment and policy-making in Croatia.

Croatian business environment is burdened with clientelism, corruption, crony capitalism ${ }^{52}$ and captured state. ${ }^{53}$ In Croatia, reforms are not implemented during favourable macroeconomic and political conditions. Instead, they are predominantly organised during crisis period or because of an outside pressure, e.g. EU membership. ${ }^{54}$ Results of policy reforms are characterised as "modernisation without development". ${ }^{55}$ Studies on policy making and policy implementation point that Government strategies lack implementation plans, steering capacity are low due to inefficient policy coordination (horizontal co-ordination between ministries) and lack of serious impact assessment studies. ${ }^{56}$ In comparison to other EU MS, Croatia has drastically lower level of participation of stakeholders in public consultations and policymaking processes. ${ }^{57}$

EU integration has contributed to many improvements in these processes, especially in the area of transparency and access to information. For example, the Government of Croatia has adopted the Code of public consultations in 2009

51 E.g. European Commission, Is EU regulation fit for new financial technologies?, Conference: \#FintechEU, 23 March 2017, [https://ec.europa.eu/info/events/finance-170323-fintech_en], accessed 10. March 2018

52 Franičević, V., Privatization in Croatia - Legacies and Context, Eastern European Economics, vol. 37, no. 2, 1999, p. 5-54; Franičević, V.; Bićanić, I., EU Accession and Croatia’s Two Economic Goals: Modern Economic Growth and Modern Regulated Capitalism, Southeast European and Black Sea Studies, vol. 7 , no. 4, 2007, p. 637-663

53 Petak, Z., Policy Making Context and Challenges of Governance in Croatia, in: Petak, Z.; Kotarski, K. (eds.) Policy-Making at the European Periphery - The Case of Croatia, Palgrave Macmillan, Switzerland, 2019, p. 29-46

54 Petek, A., Features of Croatian Public Policies, in: Petak, Z.; Kotarski, K. (eds.), ibid.; Vučković, V.; Šimić Banović, R., Who and What is stalling reforms in Croatia? Proceeding "Clientelism in Croatia", Centre for Democracy and Law Miko Tripalo, (forthcoming)

55 Fukuyama in Kotarski, K.; Petak, Z., Croatia's Post-communist Transition Experience: The Paradox of Initial Advantage Turning into a Middle-Income Trap, in: Petak, Z.; Kotarski, K. (eds.), op. cit., note 53, p. 8

56 Ibid., p. 32-37

57 Petak; Vidačak in Petak, op. cit., note 53, p. 35; Vidačak; Škrabalo in Kotarski; Petak, op. cit., note 55, p. 16 
and in 2017 central online platform for public consultation was opened which is successful in promoting public dialogue ${ }^{58}$ and there are additional areas for improvement. ${ }^{59}$

Aforementioned discussion leads to a conclusion that Croatian NRAs are currently operating in the environment, which hampers innovativeness of regulatory governance. Changes are occurring mostly due to the outside pressure and not as a Government strategic approach. Croatian NRAs are still branded as "command and control" system with traditional hierarchical principal-agent governance. Adding up non-supportive business environment and underdeveloped culture of public dialogue, transformation of financial regulatory governance will be a lengthy process. HANFA's Innovation hub will not provide revolutionary changes, but should be perceived as a positive evolutionary step in changing the culture of public dialogue, policy-making and transformation of regulatory governance.

\section{CONCLUDING REMARKS}

Fintech revolution leaders are in Asia and the US. Europe, minus the UK, is a trend follower. FinTech covers huge area, interconnecting and changing financial ecosystem. It is making great progress by providing easier access to finance for individuals and groups. It also represents risk for financial stability because, among other factors, regulatory framework is trailing behind fast-moving technical advancements.

The UK is regulatory innovator and a global leader in financial regulatory governance. They understood that innovative capacities and growth opportunities would be hindered by traditional regulatory approach. Innovation hubs and regulatory sandboxes enhance mutually beneficial dialogue. It is a platform for information sharing and learning trough collaboration. It requires partnership, flexibility, efficiency, trust and competence. This type of co-operation between regulator and (un)regulated parties has been promoted in EU's policy-making process since construction of European financial regulatory and supervisory architecture. The rest of Europe is following the UK's example, different MS being at different stage of transformation of financial regulatory governance, especially with regard to NRAs' culture and principal-agent governance.

58 Vidačak, I.; Kotarski, K., Interest Groups in the Policy-Making Process in Croatia, in: Petak, Z.; Kotarski, K. (eds.), op. cit., note 53, p. 83-106

59 European Commission, Country Report Croatia 2019 Including an In-depth Review on prevention and correction of macroeconomic imbalances, SWD(2019) 1010 final, 2019, p. 69-73, [https://ec.europa.eu/ info/sites/info/files/file_import/2019-european-semester-country-report-croatia_en.pdf], accessed 10 March 2019 
Croatia is catching up very slowly, hampered by the late EU membership and not so efficient transition to modern democracy and economic system. Case study of Croatian innovation hub in capital markets area shows that Croatia is not active in financial regulatory innovation, rather is a trend follower. Results show incremental changes in financial governance culture. Both private and public sector representatives agree that innovation hubs are constructive mechanism for grasping modern financial trends. They are perceived as a positive step forward in promoting a culture of dialogue and better policy-making. Financial governance in Croatia is still considered very strict and hierarchical. Past experiences of banking and economic crisis provide a good argument for taking a cautious approach in financial regulatory governance by the NRAs. Recommendations should therefore be focused on improving business environment, competitiveness, culture of public dialogue and enhancing institutional capacities. This benchmark report could serve as a policy paper to stimulate public dialogue and discussions on further improvement of FinTech regulatory governance in Croatia.

\section{REFERENCES}

\section{BOOKS AND ARTICLES}

1. Armour, J., et al., Principles of Financial Regulation, Oxford University Press, UK, 2016

2. Black, J., Regulatory Styles and Supervisory Strategies, in: Moloney, N.; Ferran, E.; Payne, J. (eds.) The Oxford Handbook of Financial Regulation, Oxford University Press, 2015

3. European Commission, Results of the Commission's "Exchange of views" on Financial Services Policy 2005-2010, Brussels, 18 ${ }^{\text {th }}$ July 2005, 2005

4. Ferran, E., Financial Supervision, in Mügge, D. (ed.) Europe and Governance of Global Finance, Oxford University Press, 2014, pp. 16-34

5. Ferran, E., Crisis-driven regulatory reform: where in the world is the EU going? in: Ferran, E. et al. (eds.), The Regulatory Aftermath of the Global Financial Crisis, Cambridge University Press, 2012, pp. 29-54

6. Franičević, V., Privatization in Croatia - Legacies and Context, Eastern European Economics, vol. 37, no. 2, 1999, pp. 5-54

7. Franičević, V.; Bićanić, I., EU Accession and Croatia's Two Economic Goals: Modern Economic Growth and Modern Regulated Capitalism, Southeast European and Black Sea Studies, vol. 7, no. 4, 2007, pp. 637-663

8. Kotarski, K.; Petak, Z., Croatia's Post-communist Transition Experience: The Paradox of Initial Advantage Turning into a Middle-Income Trap, in: Petak, Z.; Kotarski, K. (eds.) PolicyMaking at the European Periphery - The Case of Croatia, Palgrave Macmillan, Switzerland, 2019, pp. 1-26

9. Moloney, N., The Age of ESMA - Governing EU Financial Markets, Hart Publishing, Oxford, UK, 2018 
10. Moloney, N., The European Securities and Markets Authority and Institutional Design for the EU Financial Market - A Tale of Two Competences: Part (1) Rule Making, 12 European Business Organization Law Review, 2011, pp. 41-86.

11. Mügge, D. (ed.), Europe and Governance of Global Finance, Oxford University Press, 2014

12. Mügge, D., Introduction, in Mügge, D. (ed.) Europe and Governance of Global Finance, Oxford University Press, 2014, pp. 1-15

13. Petak, Z., Policy Making Context and Challenges of Governance in Croatia, in: Petak, Z.; Kotarski, K. (eds.) Policy-Making at the European Periphery - The Case of Croatia, Palgrave Macmillan, Switzerland, 2019, pp. 29-46

14. Petek, A., Features of Croatian Public Policies, in: Petak, Z.; Kotarski, K. (eds.) Policy-Making at the European Periphery - The Case of Croatia, Palgrave Macmillan, Switzerland, 2019, pp. 303-320

15. Posner, E., The Lamfalussy Process: Polyarchic Origins of Networked Financial Rule-Making in the EU, in: Sabel, F.; Zeitlin, J. (eds.), Experimentalist Governance in the European Union - Towards a New Architecture, 2012, pp. 43-60

16. Seawright, J.; Gerring, J., Case Selection Techniques in Case Study Research - A Menu of Qualitative and Quantitative Options, Political Research Quarterly, vol. 61, no. 2, 2008, pp. 294308

17. Stern, C., Fin Techs and their emergence in banking services in CESEE, Focus on European Economic Integration, Q3/17, Oesterreichische Nationalbank, 2017, pp. 42-58

18. Vidačak, I.; Kotarski, K., Interest Groups in the Policy-Making Process in Croatia, in: Petak, Z.; Kotarski, K. (eds.) Policy-Making at the European Periphery - The Case of Croatia, Palgrave Macmillan, Switzerland, 2019, pp. 83-106

19. Vučković, V.; Šimić Banović, R., (forthcoming) Who and What is stalling reforms in Croatia? Proceeding "Clientelism in Croatia", Centre for Democracy and Law Miko Tripalo

20. Wymeersch, E., The institutional reforms of the European Financial Supervisory System, and interim report, Financial Law Institute, Gent University, WP 2010-01, 2010

\section{WEBSITE REFERENCES}

1. Academy of Internet Finance, Sinai Lab, Cambridge Centre for Alternative Finance, The Future of Finance is Emerging: New Hubs, New Landscapes Global Fintech Hub Report, 2018, [https://www.jbs.cam.ac.uk/fileadmin/user_upload/research/centres/alternative-finance/ downloads/2018-ccaf-global-fintech-hub-report-eng.pdf], accessed 10. May 2019

2. Association of Internet Finance, TongBanJie, The Future of Finance is emerging New Hubs, New Landscapes - 2018 Global FinTech Hub Report, Hangzhou, 2018, [https://www.jbs. cam.ac.uk/fileadmin/user_upload/research/centres/alternative-finance/downloads/2018ccaf-global-fintech-hub-report-eng.pdf], accessed 10. April 2019

3. Cambridge Centre for Alternative Finance, Academy of Internet Finance, Guide to promoting financial \& regulatory innovation - Insights from the UK, University of Cambridge Judge Business School, Zheijang University, 2018, [https://www.jbs.cam.ac.uk/fileadmin/user_ upload/research/centres/alternative-finance/downloads/2018-06-ccaf-whitepaper-guide-topromoting-financial-regulation-innovation.pdf], accessed 10. April 2019 
4. Committee of European Securities Regulators - CESR, Preliminary Progress Report: Which supervisory tools for the EU securities markets? An analytical paper by CESR, Ref 04-333f, The Committee of European Securities Regulators, 2004,

5. [https://www.esma.europa.eu/sites/default/files/library/2015/11/04_333f.pdf], accessed 10. May 2019.

6. Croatian National Bank, Innovation hub, [http://fintechhub.hnb.hr/home], 2020, accessed 10. January 2020

7. CroatianNationalBank, GuvernerVujčićpredstavioInovacijskihubHNB-a,17December2019, [https:// www.hnb.hr/-/guverner-vujcic-predstavio-inovacijski-hub-hnb-a?inheritRedirect=true\&redirect=https \%3A\%2F\%2Fwww.hnb.hr\%2Fpretraga\%3Fp_p_id\%3Dcom_liferay_portal_search_web_portlet_ SearchPortlet\%26p_p_lifecycle\%3D0\%26p_p_state\%3Dmaximized\%26p_p_mode\%3Dview\%26_ com_liferay_portal_search_web_portlet_SearchPortlet_mvcPath\%3D\%252Fsearch.jsp\%26_com_liferay_portal_search_web_portlet_SearchPortlet_keywords\%3Dinovacijski\%2Bhub], accessed 10 . January 2020

8. Croatian National Bank, Annual Report 2017, CNB, 2018,

9. [https://www.hnb.hr/documents/20182/2521149/e-gi-2017.pdf/d1605b20-e073-442b8a36-704db15c051b], accessed 10. March 2019

10. Croatian National Bank, Research Priorities Programme, 2018, [https:/www.hnb.hr/documents/20182/2569921/ep21112018_istrazivacka-konferencija_dokument.pdf/4f584313e330-4f89-8d43-5752eb19dd52], accessed 10. March 2019

11. Croatian National Bank, Cooperation with institutions in the Republic of Croatia, 2015, [https://www.hnb.hr/core-functions/financial-stability/roles-and-cooperation/cooperationwith-institutions-in-the-republic-of-croatia], accessed 10. March 2019

12. Demertzis, M.; Merler, S.; Wolff, G., Capital Markets Union and the FinTech Opportunity, Journal of Financial Regulation, vol. 4, issue 1, 2018, pp. 157-165, [https://doi.org/ 10.1093/jfr/fjx012], accessed 10. March 2019

13. Deloitte, FinTech in the CEE region: Charting the course for innovation in financial services technology, Department for International Trade, Deloitte, 2016, [https://www2.deloitte. $\mathrm{com} /$ content/dam/Deloitte/global/Documents/About-Deloitte/central-europe/ce-fintechin-cee-region-2016.pdf], accessed 10. April 2019

14. European Central Bank, 2009-2019 - Surveys on Access to Finance for Enterprises, [https:// www.ecb.europa.eu/stats/ecb_surveys/safe/html/index.en.html], accessed 10. March 2019

15. ESMA, European Securities and Markets Authority, Report - The Distributed Ledger Technology Applied to Securities Markets, ESMA50-1121423017-285, 2017, [https://www.esma. europa.eu/sites/default/files/library/dlt_report_-_esma50-1121423017-285.pdf], accessed 10. March 2019

16. European Commission, Country Report Croatia 2019 Including an In-depth Review on prevention and correction of macroeconomic imbalances, SWD(2019) 1010 final, 2019, [https:// ec.europa.eu/info/sites/info/files/file_import/2019-european-semester-country-report-croatia_en.pdf], accessed 10. March 2019

17. European Commission, FinTech Action plan: For a more competitive and innovative European financial sector, $\operatorname{COM(2018)~} 109$ final, 2018, [https://eur-lex.europa. 
eu/resource.html?uri=cellar:6793c578-22e6-11e8-ac73-01aa75ed71a1.0001.02/ DOC_1\&format=PDF], accessed 10. March 2019

18. European Commission, Is EU regulation fit for new financial technologies?, Conference: \#FintechEU, 23 March 2017, [https://ec.europa.eu/info/events/finance-170323-fintech_en], accessed 10. March 2018

19. European Council, European Council meeting - Conclusions, General Secretariat of the Council, 19 October 2017, Brussels, [https://www.consilium. europa.eu/media/21620/19euco-final-conclusions-en.pdf], accessed 10. March 2018

20. European Parliament, Report on FinTech<Titre $>$ : the influence of technology on the future of the financial sector $</$ Titre $>,<$ DocRef $><$ Commission $>\{$ ECON $\}$ Committee on Economic and Monetary Affairs</Commission>, Rapporteur: <Depute $>$ Cora van Nieuwenhuizen</Depute>, 28.4.2017, [http://www.europarl.europa.eu/doceo/ document/A-8-2017-0176_EN.html], accessed 10. April 2019

21. ESAs, European supervisory authorities: European Security and Markets Authority, European Banking Authority, European Insurance and Occupational Pensions Authority, Report - FinTech: Regulatory sandboxes and innovation hubs, ESMA, EBA and EIOPA, JC 2018 74, 2019, [https://eba.europa.eu/documents/10180/2545547/JC+2018+74+Joint+Report+on +Regulatory+Sandboxes+and+Innovation+Hubs.pdf], accessed 10. May 2019

22. Financial Conduct Authority, Martin Wheatley, FCA's Project Innovate "Innovation Hub" launches, video, 2014, [https://www.youtube.com/watch?v=PmSALpjHnoo], accessed 10. March 2018

23. Financial Stability Board, Fintech and market structure in financial services: Market development and potential financial stability implications, FSB, 2019, [https://www.fsb.org/wpcontent/uploads/P140219.pdf], accessed 10. March 2019

24. Financial Stability Board, Artificial intelligence and machine learning in financial services Market developments and financial stability implications, 2017, [https://www.fsb.org/wp-content/ uploads/P011117.pdf], accessed 10. March 2019

25. Kerényi, Á., The Fintech Challenge: Digital Innovations from Post-Communist EU Member Countries, Centre for Economic and Regional Studies of the Hungarian Academy of Sciences - Institute of World Economics, 2018, pp. 1-47, [http://www.tepsa.eu/the-fintechchallenge-digital-innovations-from-post-communist-eu-member-countries-adam-kerenyiiwe-hungary/], accessed 10. April 2019

26. Lannoo, K., A crisis is a terrible thing to waste, CEPS Commentary, [https://www.ceps.eu/ wp-content/uploads/2009/08/1847.pdf], 2009, accessed 10. March 2018

27. McKinsey\&Company, FinTech decoded - Capturing the opportunity in capital markets infrastructure, Global Banking Practice, March 2018, [https://www.mckinsey.com/ /media/ McKinsey/Industries/Financial\%20Services/Our\%20Insights/Fintech\%20decoded\%20 The\%20capital\%20markets\%20infrastructure\%20opportunity/Fintech-decoded-Capturing-the-opportunity-in-capital-markets-infrastructure-final-web-version.ashx], accessed 10. April 2019

28. MSCI, MSCI Croatia Index, 2019, [https://www.msci.com/documents/10199/c0db0a48-01f2-4ba9-ad01-226fd5678111], accessed 10. April 2019 
29. MSCI, MSCI Emerging Markets Index, 2019, [https://www.msci.com/documents/10199/ c0db0a48-01f2-4ba9-ad01-226fd5678111],_accessed 10. April 2019

30. Raiffeisen Bank International, CEE FinTech Atlas 2018 - Exclusive insights into 19 Fintech ecosystems in Central and Eastern Europe, 2019, [http://www.fintechatlas.com/], accessed 10. April 2019

31. UNSGSA FinTech Working Group and CCAF, Early Lessons on Regulatory Innovations to Enable Inclusive FinTech: Innovation offices, Regulatory Sandboxes, and RegTech, Office for the UNSGSA and CCAF: New York, NY and Cambridge, UK, 2019, [https://www.unsgsa. org/files/2915/5016/4448/Early_Lessons_on_Regulatory_Innovations_to_Enable_Inclusive_FinTech.pdf], accessed 10. March 2019

32. Zeitlin, J., Transnational Transformation of Governance - The European Union and Beyond, Vossiuspers UvA, Amsterdam, 2010, [https://pure.uva.nl/ws/files/1507269/93675_342972. pdf], accessed 10. March 2019

33. Ziegler, T. et al., Shifting Paradigms - The $4^{\text {th }}$ European Alternative Finance Benchmarking Report, Cambridge Centre for Alternative Finance University of Cambridge Judge Business School, University of Agder School of Business Law, Invesco, CME Group Foundation, 2019, [https://www.jbs.cam.ac.uk/fileadmin/user_upload/research/centres/alternativefinance/downloads/2019-04-4th-european-alternative-finance-benchmarking-industryreport-shifting-paradigms.pdf], accessed 10. March 2019

34. World Bank, Doing Business 2019 - Training for Reform, 16 $6^{\text {th }}$ edition, 2019, [http://www. doingbusiness.org/content/dam/doingBusiness/media/Annual-Reports/English/DB2019report_web-version.pdf], accessed 10. May 2019

35. World Economic Forum, The Europe 2020 Competitiveness Report, Building a more competitive Europe, 2014, [http://www3.weforum.org/docs/WEF_Europe2020_CompetitivenessReport_2014.pdf], accessed 10. May 2019

36. World Economic Forum \& Deloitte, Beyond Fintech: A pragmatic assessment of disruptive potential in financial services, Part of the Future of Financial Services series, 2017, [http:// www3.weforum.org/docs/Beyond_Fintech_-_A_Pragmatic_Assessment_of_Disruptive_ Potential_in_Financial_Services.pdf], accessed 10. May 2019

37. World Economic Forum\& Deloitte, The Future of Financial Services - How disruptive innovations are reshaping the way financial services are structured, provisioned and consumed, An industry project of the Financial Services Community, Final Report, 2015, [http://www3. weforum.org/docs/WEF_The_future_of_financial_services.pdf], accessed 10. May 2019 


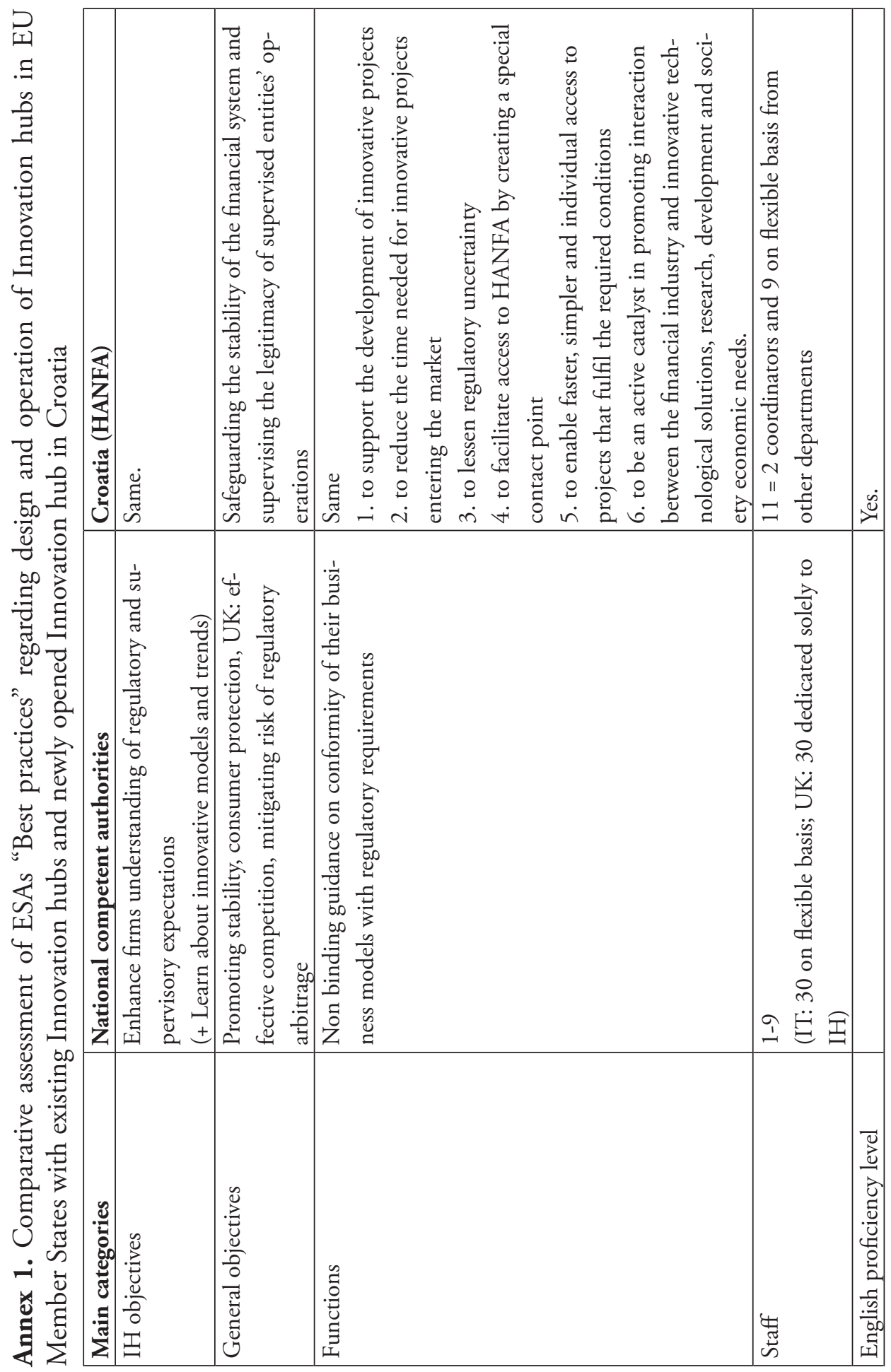




\begin{tabular}{|c|c|c|c|c|c|c|c|c|c|}
\hline & 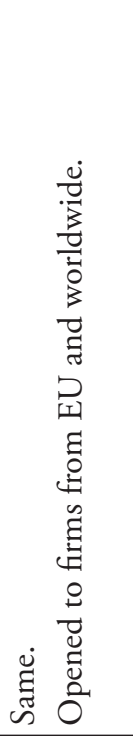 & 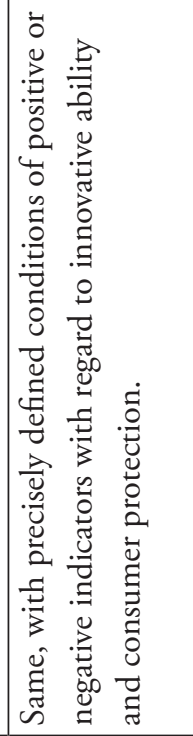 & & $\begin{array}{l}\text { घี } \\
\text { जू }\end{array}$ & 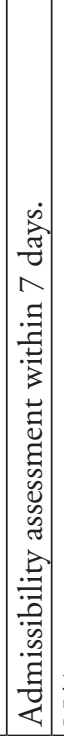 & 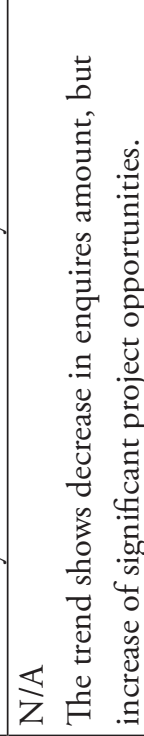 & 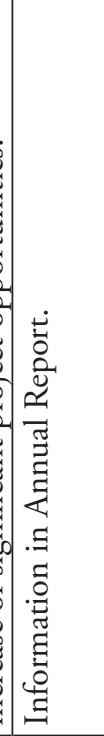 & 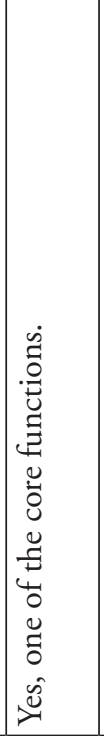 & 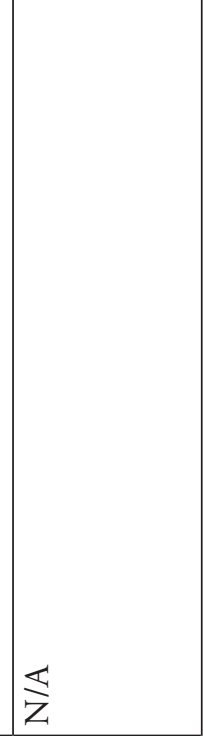 \\
\hline & 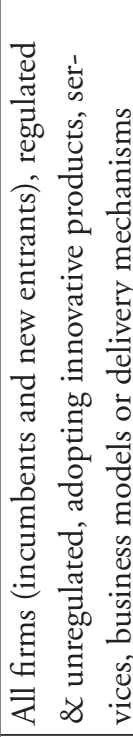 & 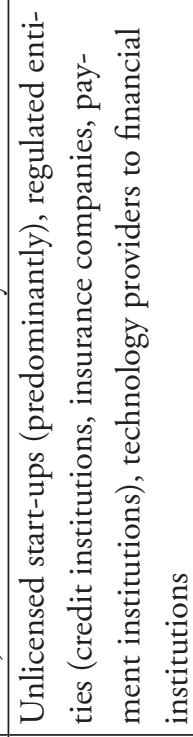 & 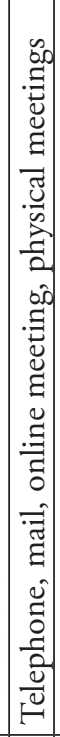 & 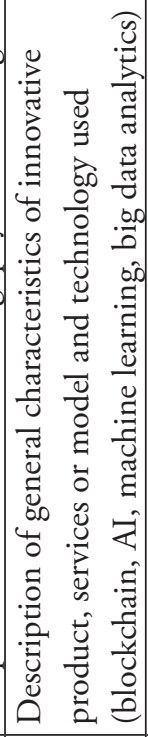 & & 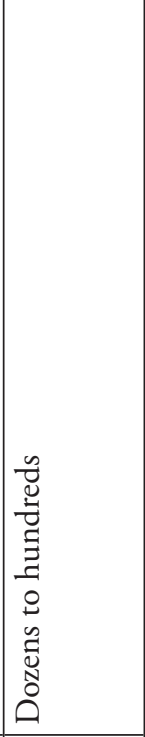 & 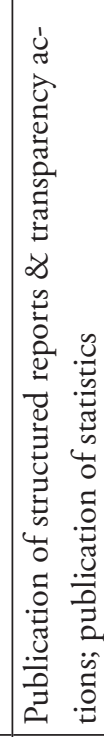 & 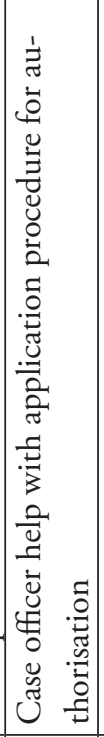 & 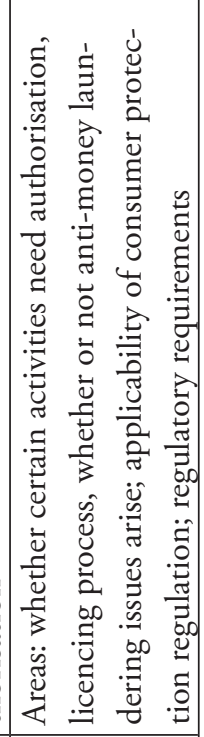 \\
\hline & & 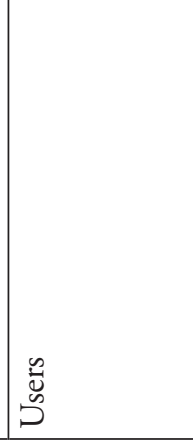 & & 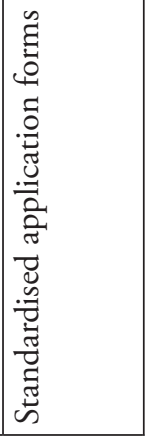 & 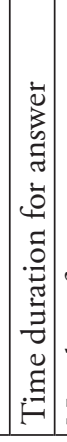 & 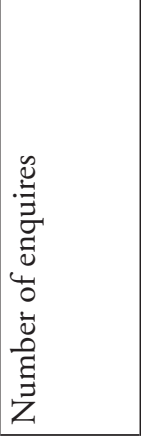 & 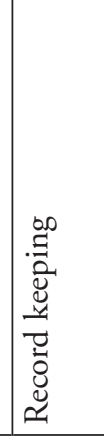 & 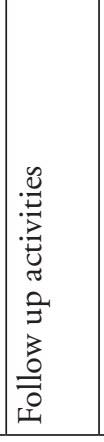 & 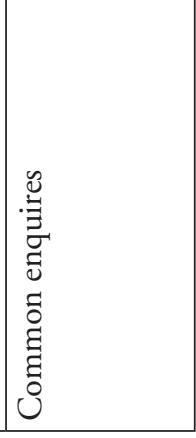 \\
\hline
\end{tabular}




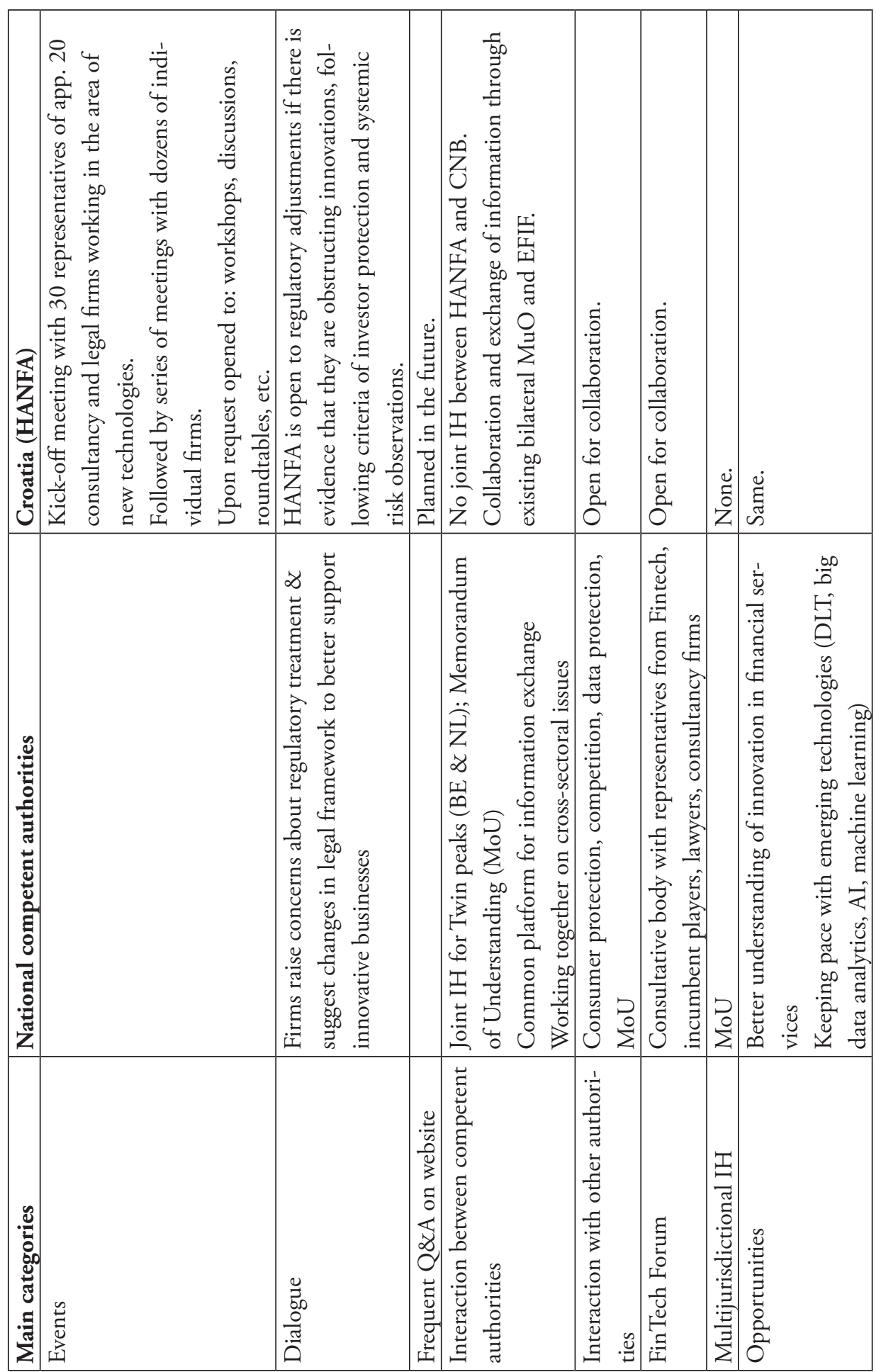




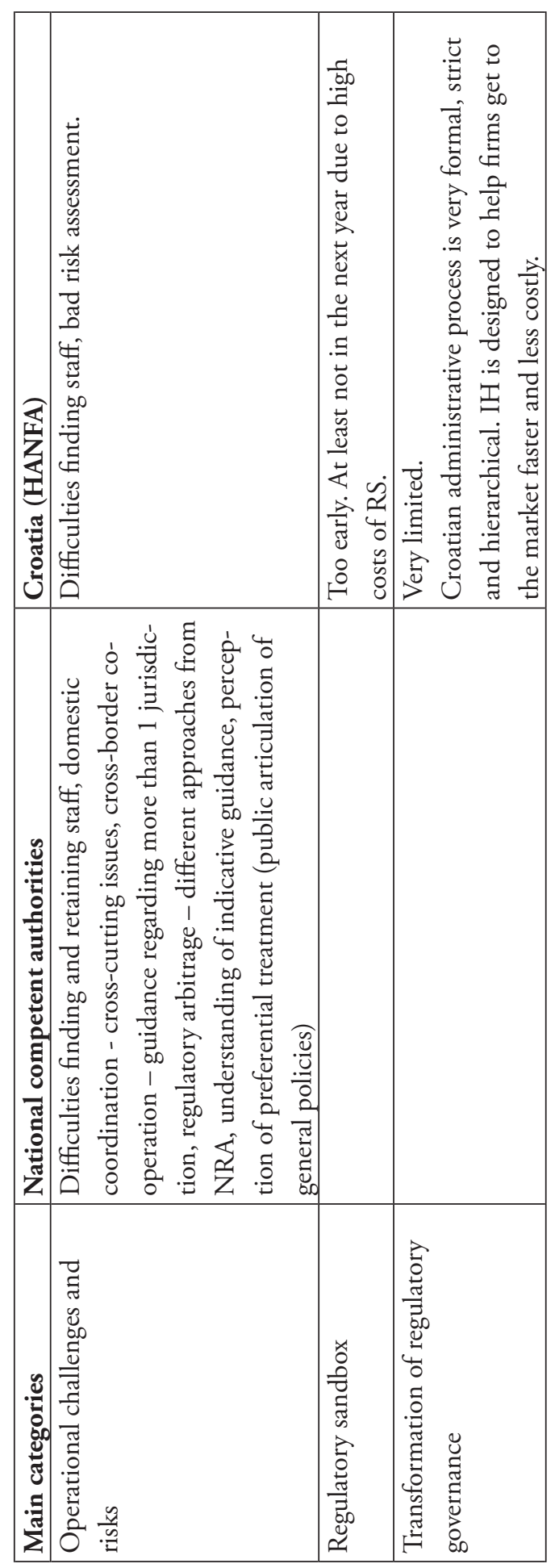

Ivana Bajakić: TRANSFORMATION OF FINANCIAL REGULATORY GOVERNANCE THROUGH... 
Annex 2. Comparative assessment of FCA'a and HANFA's Innovation Hub operational activities according to most different case selection

\begin{tabular}{|l|l|}
\hline UK (FCA) & Croatia (HANFA) \\
\hline \multicolumn{2}{|c|}{ STARTING POINT } \\
\hline 2-3 people start the project in 2014 & 2-3 people \\
\hline Culture of innovation & Culture of trend-following \\
\hline \multicolumn{2}{|c|}{ SUPPORT FROM LEADERSHIP } \\
\hline Highest level of leadership & $\begin{array}{l}\text { Support from HANFA leadership } \\
\text { Initiated at HANFA level (highest levels of } \\
\text { Government not engaged in the process) }\end{array}$ \\
\hline $\begin{array}{l}\text { Call for Input - to identify key issues and } \\
\text { challenges facing innovator businesses }\end{array}$ & No. \\
\hline $\begin{array}{l}\text { Methodology - public consultation: ideation, } \\
\text { creation and ongoing formulation of RS \& } \\
\text { Innovative agenda } \\
\text { 1. provided CFA with external expertise, } \\
\text { insight to steer direction and focus of FCA } \\
\text { regulatory \& innovation activities }\end{array}$ & $\begin{array}{l}\text { Methodology - Following ESAs policy paper: } \\
\text { "Principles for establishment and operation } \\
\text { of innovation facilitators" in European Su- } \\
\text { pervisory Agencies (ESAs) Report: FinTech: } \\
\text { Regulatory sandboxes and innovation hubs } \\
\text { (April 2018) }\end{array}$ \\
$\begin{array}{l}\text { Identify trends and potential issues at early } \\
\text { stage }\end{array}$ & \\
$\begin{array}{l}\text { 3. Engagement of FCA team } \\
\text { 4. New information can help identify pos- } \\
\text { sible policy and process changes }\end{array}$ & \\
5. Provides demonstration of FCA commit- \\
ment \\
$\begin{array}{l}\text { 6. Consultation process useful if incumbents } \\
\text { are opposing pro-innovation initiatives }\end{array}$ \\
$\begin{array}{l}\text { 7. increase the impact beyond firms directly } \\
\text { involved - world leader of regulatory in- } \\
\text { novation }\end{array}$ & \\
\hline $\begin{array}{l}\text { Findings: } \\
\text { - difficulties to navigate the regulatory system } \\
\text { - lack of legal certainty \& clarity } \\
\text { - regulatory uncertainty (e.g. digital curren- } \\
\text { cies) } \\
\text { - accessing bank accounts for small businesses } \\
\text { - inadequate FCA website information }\end{array}$ & \\
\hline
\end{tabular}




\begin{tabular}{|c|c|}
\hline \multicolumn{2}{|c|}{ ENGAGEMENT ACTIVITIES } \\
\hline $\begin{array}{l}\text { 1. Roundtables - to focus on the FCA \& the } \\
\text { Innovation Hub asking for feedback to im- } \\
\text { prove operations }\end{array}$ & $\begin{array}{l}\text { Kick-off meeting with } 30 \text { representatives of } \\
\text { app. } 20 \text { consultancy and legal firms working } \\
\text { in the area of new technologies. } \\
\text { Planning for more meetings with: start-ups, } \\
\text { IT community, regulated entities. }\end{array}$ \\
\hline $\begin{array}{l}\text { 2. Surgeries - to provide support to busi- } \\
\text { nesses experiencing specific and common } \\
\text { issues working with the regulatory framework, } \\
\text { including Q\&A sessions to explore problems } \\
\text { and coaching sessions to educate attendees }\end{array}$ & $\begin{array}{l}\text { None at the moment, can be organised upon } \\
\text { demand. }\end{array}$ \\
\hline $\begin{array}{l}\text { 3. Thematic workshops - to draw on indus- } \\
\text { try expertise to discuss emerging trends in the } \\
\text { sector and consider potential impact from a } \\
\text { regulatory perspective. }\end{array}$ & $\begin{array}{l}\text { None at the moment, can be organised upon } \\
\text { demand. }\end{array}$ \\
\hline $\begin{array}{l}\text { 4. Monthly 'Showcase Events' - to allow } \\
\text { firms to talk through potential solutions to } \\
\text { common problems }\end{array}$ & $\begin{array}{l}\text { None at the moment, can be organised upon } \\
\text { demand. }\end{array}$ \\
\hline $\begin{array}{l}\text { 5. Events and conferences - to enable a wide } \\
\text { range of stakeholders to participate and en- } \\
\text { gage in a variety of issues, topics and themes }\end{array}$ & $\begin{array}{l}\text { None at the moment, can be organised upon } \\
\text { demand. }\end{array}$ \\
\hline $\begin{array}{l}\text { 6. Consultation processes - that openly } \\
\text { invite input and perspectives from a whole } \\
\text { range of stakeholders, from industry experts } \\
\text { and practitioners to the general public }\end{array}$ & $\begin{array}{l}\text { None at the moment, can be organised upon } \\
\text { demand. }\end{array}$ \\
\hline $\begin{array}{l}\text { 7. Innovation sprints - to bring together } \\
\text { multiple stakeholders to address and collec- } \\
\text { tively solve a specific problem identified }\end{array}$ & $\begin{array}{l}\text { None at the moment, can be organised upon } \\
\text { demand. }\end{array}$ \\
\hline $\begin{array}{l}\text { workshops, roadshows, roundtables, confer- } \\
\text { ences and panel sessions - hosted by other } \\
\text { organisations }\end{array}$ & $\begin{array}{l}\text { Lectures and workshops with stakeholders at } \\
\text { the Croatian Chamber of Commerce }\end{array}$ \\
\hline $\begin{array}{l}\text { 2018: } 100 \text { firms involved in RS directly \& } \\
\text { thousands of firms indirectly }\end{array}$ & N/A \\
\hline $\begin{array}{l}\text { Importance of high levels of external engage- } \\
\text { ment with a wide variety of stakeholders is } \\
\text { therefore an essential element to an effective } \\
\text { and high impact process of innovation. }\end{array}$ & $\begin{array}{l}\text { Culture of stakeholder meetings with public } \\
\text { dialogue, public questions and consultations } \\
\text { are underdeveloped in Croatia. }\end{array}$ \\
\hline
\end{tabular}




\begin{tabular}{|l|l|}
\hline \multicolumn{2}{|c|}{ Internalising Innovation } \\
\hline $\begin{array}{l}\text { Working closely with firms to develop, co- } \\
\text { create and redefine the design, processes and } \\
\text { approaches to supervision, monitoring and } \\
\text { regulation itself }\end{array}$ & $\begin{array}{l}\text { IH could provide a window of opportunity } \\
\text { for adjustments in regulatory framework. } \\
\text { However, the Croatian administrative process } \\
\text { is very formal, strict and hierarchical. IH is } \\
\text { primarily designed to help firms get to the } \\
\text { market faster and less costly. }\end{array}$ \\
\hline $\begin{array}{l}\text { Facilitate Innovation: } \\
\text { 1. } 12 \text { Proof of Concepts (redefine regulatory } \\
\text { reporting for both regulator and the regu- } \\
\text { lated) } \\
\begin{array}{l}\text { 2. RegTech Team's TechSprints (Proof of con- } \\
\text { cepts to address specific industry challenges, } \\
\text { e.g. money \& mental health) }\end{array}\end{array}$ & None. \\
\hline \multicolumn{2}{|c|}{ International Cooperation } \\
\hline $\begin{array}{l}\text { Collaboration agreements: China, Singapore, } \\
\text { Hong Kong, South Korea, Australia, Canada }\end{array}$ & Member of EFIF. \\
\hline $\begin{array}{l}\text { GFIN - Global Financial Innovation Net- } \\
\text { work }\end{array}$ & No. \\
\hline \multicolumn{2}{|c|}{ Outcome } \\
\hline $\begin{array}{l}\text { Too early but indications that Project Inno- } \\
\text { vate is: } \\
\text { - resulting in new firms investing in new gen- } \\
\text { eration technologies } \\
\text { - better financial products and services } \\
\text { - promote competition } \\
\text { - build regulator's capacity to enhance integ- } \\
\text { rity of financial service }\end{array}$ & N/A \\
\hline $\begin{array}{l}\text { World leader - Influential trend-setting centre } \\
\text { for financial \& regulatory innovation. }\end{array}$ & Trend-follower. \\
\hline
\end{tabular}

